\title{
ABDUL RASYID WAHAB PESAN KEBINEKAAN DARI TANAH SIKKA, MAUMERE
}

\author{
$\frac{\text { David Krisna Alka }}{\text { davidkrisna@gmail.com }}$
}

\section{Latar Belakang Abah Rasyid}

Abdul Rasyid Wahab. Masyarakat Muslim Maumere, Kabupaten Sikka, Flores, NTT, akrab menyapanya Abah Rasyid. Leluhur Abah Rasyid adalah keturunan Gowa. Penduduk Sikka menyebut orang dari Gowa berarti orang Islam. Terbukti, dalam syair-syair daerah Sikka, sering disebut bahwa orang-orang Gowa adalah orang Islam.

Kedatangan orang Islam Gowa ke Sikka menjadikan Maumere lebih beragam, ditambah pendatang lain dari Pulau Jawa yang kemudian banyak bermukim di daerah pantai. Jauh sebelum sekarang, para leluhur Abah Rasyid sudah berperan dalam menjaga kerukunan dalam kemajemukan di tanah Maumere.

Peran itu dilanjutkan Abah Rasyid sejak masih muda. Abah Rasyid berkerabat dengan saudara-saudaranya yang beragama Katolik. Leluhurnya memilki hubungan saudara hasil dari perkawinan dengan Raja dari Sikka, Raja Thomas (masih saudara kakek).

Sebelum Indonesia Timur merdeka (1945-1947) Abah Rasyid menempuh Pendidikan di Sekolah Desa Katolik Maumere dan Algemeene Laager School, Maumere (1948-1949). Kemudian Sekolah Dasar Maumere (1949-1953). Abah menempuh Pendidikan di sekolah Katolik di SMP Yapentom, Maumere dan SMA Suryadikara, Ende. Pada tahun 1960 sempat kuliah dan bekerja di Universitas Atmajaya, Jakarta yang didirikan Tokoh Nasional dari Flores, Frans Seda. Abah hanya setahun di Jakarta. 
Saat peristiwa G30 S/PKI Abah pulang ke Maumere. Kemudian menikah dan mulailah Abah menjadi pengurus masjid, aktivis masjid, membangun masjid, dan berperan aktif di Sikka.

Pada tahun 1968 Abah masuk pemerintahan Maumere. Abah menjadi anggota Badan Pemerintah Harian (BPH) Kab. Sikka. Abah dari utusan umat Muslim, menjadi pembantu Bupati dalam urusan tertentu. Usianya saat itu baru 26 tahun. Kemudian setelah di BPH, tahun 1970 Pemilu di Sikka ada dua Partai Islam, Partai NU dan Parmusi. Abah sebenarnya Parmusi, tetapi saat itu Partai NU tidak ada kader yang menjadi calon anggota DPRD Kab Sikka. Kemudian, Partai NU dan Parmusi bergabung mengutus Abah menjadi anggota DPRD utusan NU dan Parmusi.

Cuma setahun Abah menjadi anggota DPRD (1972-1973). Setelah itu Abah menjadi PNS Tingkat II Sikka. Bupati Sikka saat itu, L. Say (Katolik), banyak menuntun dan membuat Abah menjadi lebih aktif serta diajak dalam berbagai kegiatan. Abah banyak mendapat pencerahan dari Bupati L. Say (L. Say menjadi nama pelabuhan di Maumere).

Abah lalu menunaikan tugas belajar di APDN, Kupang (1973-1976). Lulus dari APDN, bertugas di bagian Kesra, Kab, Sikka (1979-1981), menjadi Koordinator Pemerintahan Kota (Kopeta) Maumere (1982-1987), BAPPEDA Kab Sikka (1987-1992). Tahun 1993, Abah pensiun.

Tahun 1982 Abah sudah aktif di Pemuda Muhammadiyah Kecamatan. Sejak menjadi Kopeta Abah sudah menjadi Pengurus Cabang Muhammadiyah Sikka. Abah menjadi pengurus tidak memaksakan diri tapi memang dibutuhkan. Kemudian diangkat menjadi Wakil Ketua Pimpinan Daerah Muhammadiyah (PDM) Sikka (1985-1981).

Abah menjadi salah satu tokoh Muhammadiyah Sikka yang memiliki peran besar dalam membentuk Pimpinan Cabang Muhammadiyah di Kab Sikka, termasuk pendidikan dan amal usaha di setiap cabang Muhammadiyah. Abah menjadi Ketua PDM Sikka dari tahun 1991 sampai 2015.

Abah juga menjadi Ketua Majelis Ulama Indonesia (MUI) Kab, Sikka dari tahun 1996-2001. Menjadi Wakil Ketua Forum Kerukunan Umat Beragama (FKUB) Kab. Sikka (2005-sekarang). Di mana Ketua FKUB adalah dari Keuskupan. Di usianya yang lebih 70 tahun, Abah menjadi Ketua Dewan Penasehat MUI Kab Sikka dan Ketua Dewan Penasehat PDM Kab Sikka. 
Sampai sekarang, sulit mencari tokoh sepuh Muslim yang mengayomi dan menjadi tokoh masyarakat seperti Abah di Maumere, Kab Sikka. Abah Rasyid yang lahir di Maumere, 5 April 1937 ini menjadi tokoh utama dan rujukan pertama bagi masyarakat, pemerintahan, dan ormas, tatkala ada kegiatan, penelitian, dan terkait peristiwa sosial keagamaan di Kab Sikka.

Untuk diketahui, penduduk Kabupaten Sikka 91\% beragama Katolik, mulai tahun 2005 menjadi keuskupan baru, yakni keuskupan Maumere, di bawah Keuskupan Agung Ende. Kawasan pesisir utara cukup banyak dihuni oleh warga keturunan etnik Tidung-Bajo, Bugis serta Jawa dan Tionghoa.

Penduduk Kabupaten Sikka tersebar di 21 kecamatan, kawasan berpenduduk padat adalah di kawasan utara yang berbatasan dengan Laut Flores, sedang kawasan selatan yang berbatasan dengan Laut Sawu/Lautan Hindia berpenduduk jarang. Konsentrasi penduduk perkotaan ada di Kota Maumere dan kawasan Geliting di Kewapante. Kini sekitar 11 persen (4 persen di pulau) atau 40 ribu penduduk Kab Sikka Muslim dari 331 jiwa penduduk Sikka.

\section{Peristwa Pencemaran Hosti dan Kematian Tibo}

Tahun 1995 terjadi peristiwa pencemaran Hosti pertama di Maumere. Peristiwa Hosti pertama terjadi pada tahun 1995. Kejadian bermula ketika ada seorang pemuda dari luar Pulau Flores, pemuda desa, yang ikut kakaknya kerja proyek. Pemuda tersebut masuk dalam gereja dibawa teman-temannya yang beragama Katolik.

Pemuda itu ikut komini Hosti. Tapi dia tidak memakan roti Hosti tersebut seperti yang lain. Roti Hosti malah diremasnya. Umat Katolik berang karena pemuda tersebut menghina. Pemuda itu mau digebuk dan dikeroyok. Lalu diamankan polisi dan ditahan di polres. Banyak warga yang demo ke polres dan mau menghakimi pemuda tersebut.

Lalu isu pun berkembang. Isunya Islam telah menghina perisriwa Hosti. Kerusuhan terjadi. Toko dan warung milik Muslim banyak dibakar. Kebengisan terjadi. Abah Rasyid ditelepon ada kabar bahwa umat Muslim malam-malam sudah siap balas menyerang. Namun Abah meredakan umat Muslim Maumere supaya tidak balik melawan.

"Saya bilang tidak usah, biar polisi saja. Pagi-pagi saya diundang pertemuan bupati dan tokoh-tokoh. Saya agak keras waktu itu. Kenapa yang Islam saja kena. 
Kita tidak tahu pelaku itu siapa. Ini SARA. Saya keliling dan beri semangat umat Muslim untuk tetap bertahan di sini. Saya hanya ikut saja mereka, dan mengajak supaya jangan dendam. Ada yang mengatakan ini suatu ujian dan cobaan, mungkin kami punya kesalahan sehingga terjadi musibah ini” ungkap Abah Rasyid.

Abah Rasyid keliling menengok jemaah. Banyak yang mengatakan peristiwa itu adalah ujian dalam hidup. Setelah peristiwa itu, Abah minta bupati untuk membantu para korban. Abah ketika masih menjabat sebagai sekretaris MUI.

Tahun 2002 terjadi lagi. Kronologis kejadiannya bermula dari merapatnya kapal turis bernama "Monalisa" dipelabuhan Maumere untuk menurunkan para turis yang ingin berlibur di Maumere dan sekitarnya. Ada anak buah kapal tersebut yang memasuki gereja Katolik Santo Josef pada saat diadakan ibadat misa kudus. Pada saat umat maju ke altar untuk menerima komuni berupa hosti kudus ada seorang anak buah kapal yang ikut menerima hosti, tetapi kemudian merusaknya. Pelakunya Protestan punya KTP dua.

Hal ini menimbulkan reaksi dari umat Katolik. Kemarahan dan amuk massa terjadi. Peristwia ini mengakibatkan sebagian kantor Polres Maumere dan beberapa warung disepanjang jalan menuju pelabuhan rusak. Pengrusakan terjadi saat massa mengejar anak buah kapal yang berlari menuju kapalnya dipelabuhan. Karena aktifnya polisi dan TNI sehingga peristiwa ini tidak meluas. Abah keliling menemui umat Muslim, mereka tidak apa-apa. Hanya ada pengrusakan di masjid perumnas. Abah ikut pendapat umat, ini ujian hidup. Abah juga menyampaikan ke bupati untuk membantu para korban.

Peristiwa eksekusi hukuman mati Tibo cs juga menimbulkan gejolak di Maumere. Peran Abah strategis ketika merendam supaya konflik Muslim dan Katolik tidak melebar. Ketika Tibo dihukum mati, Abah diundang dan menyaksikan penguburan.

\section{Peran Muhammadiyah di Maumere}

Tahun 1985 Abah Rasyid mulai masuk Muhammadiyah. Bersama beberapa tokoh Muhammadiyah di Maumere, Abah mengawali perkembangan Muhammadiyah di Maumere dengan memanfaatkan tanah wakaf. Saat itu, Muhammadiyah baru memiliki satu cabang di Kab. Sikka. Kini PDM berkembang, sekarang ada lima PCM di Kab Sikka. Setiap PCM ada amal usaha. Mulai TK sampai SMA. Pokoknya tiap cabang, ada masyarakat memberikan wakaf. 
Abah menjadi tokoh penting dalam gerakan Muhammadiyah di Kab Sikka. Di bidang pendidikan, ketika bermusyawarah akan mendirikan sekolah, Abah berdialog dengan warga. Banyak bapak-bapak di sini dalam sehari menghabiskan lebih dari sebungkus rokok. Saat itu harga rokok satu batang masih seribu. Ada warga yang mengaku sehari bisa menghabiskan 2 bungkus. Abah hanya minta satu batang rokok sehari untuk uang sekolah anak-anak mereka. Abah minta 10 ribu rupiah. Mendengar sindirian Abah, mereka lebih semangat dan menaikkan menjadi 20 ribu rupiah

Ketika sekolah Muhammadiyah belum dibangun, anak-anak pernah meminjam kelas dari Sekolah Katolik. Untuk perguruan tinggi, program kuliah dimulai tahun 2000 di bawah PDM Kupang. IKIP Muhammadiyah Maumere dulu bekerja sama dengan kampus di Kupang sampai tahun 2009. Tahun 2013 baru diberi izin operasional. Mahasiwa IKIP Muhammadiyah 70 persen Katolik dan dosen dan pengajarnya 50 persen Katolik. Dana IKIP meminjam wakaf tunai dari Universitas Muhammadiyah Surakarta, pembayarannya diangsur.

Di Sekolah Muhammadiyah ada guru yang militan beragama Katolik. IKIP Muhammadiyah sekitar 700-an mahasiswa (82 persen katolik). Dua SMP jumlah siswa sekitar 310 (70 persen katolik) dan satu SMA (15 persen siswanya Katolik). Muhammadiyah Sikka memilki satu kampus IKIP Muhammadiyah, 2 SMP, 4 MTS, 1 SMA, dan 1 Madarasah Aliyah.

Pada tahun 1993, Abah Rasyid mendirikan Panti Asuhan. Panti Asuhan langsung di tangani oleh Abah Rasyid. Ada 50 anak. Semua sekolah, yang sudah tamat sekolah ada yang sarjana dan mengajar. Berdirinya panti karena ada bencana di pinggir pantai dan di Pulau Babi yang kebetulan mayoritas Muslim. Saat itu Abah melakukan survey anak-anak yatim dan anak terlantar akibat bencana. Abah menemukan 360 anak korban bencana dan anak-anak yang tidak dihiraukan. Awalnya hanya ada tenda penampungan dan dapur umum.

Sekarang sudah ada 5 anak panti yang sudah sarjana. Ada yang menjadi Guru SMA, menjadi Imam masjid. Kebanyak mereka anak-anak orang pulau. Pengasuh pertama adalah Abah dan Umi (istri Abah). Soalnya, tidak ada orang yang berani mengasuh dan memimpin panti, karena gaji satu bulan satu juta makan di sini, orang banyak tidak mau. 15 anak asuh dikirim kuliah di UMM, Unismu Makasar, dan UMS. Sekarang panti asuhan itu dibawah asuhan anaknya, Ihsan. 
Selain itu, Abah pernah punya pengalaman pada tahun 1981 menjadi Sakorlak bencana alam di Pulau Palue. Ketika ada bencana di Palue semua pegawai tidak mau, padahal mereka Katolik dan korban sebagian besar Katolik. Abah turun tangan dan melakukan relokasi, evakuasi, dua bulan dia di Pulau Palue. Abah tidak solat jumat karena tidak ada jemaah, semua polisi Katolik dan Kristen.

Tahun 2013, Gunung Rokatenda meletus di Pulau Palue, Kabupaten Sikka, Nusa Tenggara Timur. Abah berperan penting dan memimpin team MDMC beraksi saat meletusnya Gunung Rokatenda dan beberapa kegiatan pasca meletusnya gunung tersebut.

Tidak hanya ketika Gunung Rokatenda meletus, bantuan kepada masyarakat yang mengungsi paska meletusnya Gunung Rokatenda juga diberikan MDMC setempat. Termasuk memberikan hiburan kepada para pengungsi oleh Ikatan Pelajar Muhammadiyah (IPM) maupun Nasyiatul Aisyiyah (NA) setempat demikian juga memberikan bantuan bimbingan pendidikan kepada anak-anak yang mengungsi.

Abah juga bermimpi ingin memberikan pelayanan kesehatan bagi masyarakat Kabupaten Sikka NTT yang tersebar di 8 pulau, yaitu keinginan membangun puskesmas terapung. Kini mimpi Abah terwujud, Kapal Kemanusiaan itu kini sudah siap berlayar memberikan bantuan kesehatan untuk warga di kepulauan.

Mimpi Abah selanjutnya adalah ingin bikin SMK Kelautan (baru dapat tanah satu hektar) dan mau membangun rumah sakit (belum punya tanah). Namun, balai pengobatan sudah dimulai di Wuring, Sikka.

\section{Merawat kebersamaan dalam kebinekaan}

Beruntung Abah memiliki kekerabatan yang tersebar di NU dan Muhammadiyah Sikka. Beberapa kerabatnya ada yang menjadi pimpinan NU Sikka dan pimpinan Muhammadiyah, kebetulan semua kerabat, sepupuan, saudara, sampai sekarang. Sehingga lebih mudah mencapai kesepakatan ketika ada perbedaan. NU dan Muhammadiyah masing-masing punya sistem. Yang pasti tidak ada masalah NU-Muhammadiyah di Kab. Sika dan Maumere.

Bersama umat Katolik pun begitu. Abah sampai sekarang masih menjabat Wakil Ketua FKUB. Toleransi sudah lama ditanamkan oleh Raja sikka. Ketika para pedagang datang, Raja menjadi pelindung dan memberi hak hidup. 
Di Sikka Uskup sangat berperan. Walau Abah sudah tidak lagi menjadi Ketua MUI dan Ketua PDM, banyak yang masih menganggap Abah masih ketua. Abah bahkan pernah diminta sampai mati menjabat posisi tersebut. Abah tidak mau, dia ingin ada regenerasi, kader perlu disiapkan.

"Kita sebagai pemimpin harus melahirkan pemimpin. Pisang itu mati setelah anak-anaknya

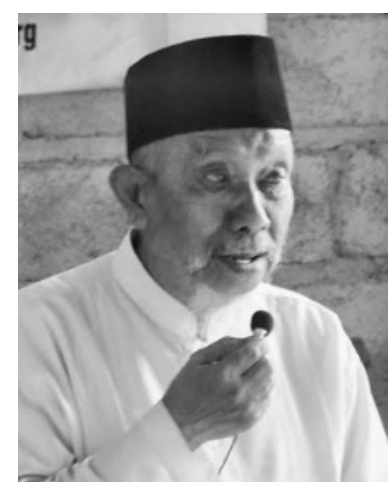
sudah berbuah" ungkap Abah. Abah sampai sekarang masih aktif menghadiri acara atau undangan dari pihak mana pun. Mengikuti acara Doa Bersama supaya kita rukun. "Semua hal yang dirasakan orang lain kita juga merasa, tidak sampai mengorbankan akidah. Laku dan Mulut itu untuk kebaikan” tegas Abah. Abah juga menghadiri acara Natalan di polres, kantor bupati, hanya Abah yang diundang. Tidak ada yang mengeluh. Setiap kerabat non muslim ada acara atau pesta, Abah selalu hadir. Kalau ada makan babi, mereka sudah berikan tempat khusus makanan non babi.

Abah mengaku, semua yang dia lakukan selama ini dari orang tua sudah turun temurun. Orang tua Abah juga dikenal tokoh Muslim berpengaruh di Sikka waktu dulu.

"Kita sudah datang dari dulu hidup bersama sudah turun temurun. Kita jaga terus. Dulu dan sekarang cara berbuat baik berbeda caranya. Berikhtiar, sabar, kita harus punya idealisme. Tahta dan harta itu di dunia saja” ungkap Abah. 